\title{
Pertumbuhan dan Kandungan Flavonoid Bayam Merah (Alternanthera amoena Voss) pada Media Tanam dengan Pemberian Asam Humat dan Urea
}

\author{
Rezza Adianti*, Elly Proklamasiningsih, Nurtjahjo Dwi Sasongko
}

\author{
Fakultas Biologi, Universitas Jenderal Soedirman \\ Jalan dr. Suparno 63 Purwokerto 53122 \\ *Email : rezzaadianti@gmail.com
}

Rekam Jejak Artikel:

Diterima : 28/08/2019

Disetujui : 30/10/2019

\begin{abstract}
Red spinach (Alternanthera amoena Voss) is a fibery vegetable plant. The leaves contain primary metabolites such as vitamins A, B1, B2, C and niacin, as well as minerals such as Fe, $\mathrm{Ca}, \mathrm{Mn}$, and P. It also contains secondary metabolites such as flavonoids which is potential to be used as antioxidants. The purpose of this study was to determine the effect of humic acid as organic fertilizer and urea as inorganic fertilizer on growth and flavonoid content of red spinach and determine the best concentration of humic acid and urea. The research was carried out experimentally, by using a completely randomized design (CRD) with a factorial consisting of two factors with each of the 4 levels. The first factor is humic acid concentration that was 0 (absent); 4 g. $\mathrm{kg}^{-1} ; 8$ g. $\mathrm{kg}^{-1}$; and $12 \mathrm{~g} . \mathrm{kg}^{-1}$. The second factor was urea concentration at $0 ; 0.4$

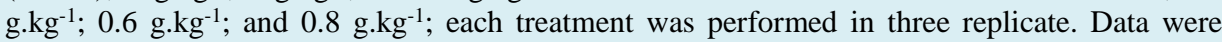
analyzed by ANOVA (Analysis of Variance), was then to an LSD test. Interestingly, application of urea fertilizer show at the concentration of $4 \mathrm{~g} \cdot \mathrm{kg}^{-1}$ was the most effective concentration in increasing both fresh and dry weight, but however if the urea was combined with humic acid at all concentration applied did not show any significant difference to all parameters; fresh, dry weight as well as flavonoid content.
\end{abstract}

Keywords: Alternanthera amoena Voss, flavonoid, humic acid, plant growth, urea

\begin{abstract}
Abstrak
Bayam merah (Alternanthera amoena Voss) merupakan tanaman sayur yang mengandung banyak serat, vitamin, mineral serta flavonoid yang berpotensi sebagai antioksidan. Tujuan dari penelitian ini untuk mengetahui pengaruh pemberian pupuk organikasam humat dan anorganik ureaterhadap pertumbuhan dan kandungan flavonoid tanaman bayam merah dan mengetahui konsentrasiasam humat dan urea yang paling berpengaruh, serta interaksi keduanya dalam meningkatanpertumbuhan dan kandungan flavonoid tanaman bayam merah. Penelitian termasuk eksperimental denganRancangan Acak Lengkap (RAL) Faktorial yang terdiri atas dua faktor dengan 4 taraf. Faktor pertama pemberian asam humat konsentrasi 0 (kontrol); 4 g.kg-1; 8 g.kg ${ }^{-1}$; dan 12 g. $\mathrm{kg}^{-1}$. Faktor kedua berupa pemberian urea dengan taraf konsentrasi 0 (kontrol); 0,4 g.kg-1; 0,6 g.kg-1; dan 0,8 g. $\mathrm{kg}^{-1}$; masing masing perlakuan diulang sebanyak tiga kali.Data dianalisis dengan ANOVA (Analysis of Variance kemudian dilanjutkan dengan uji BNT. Pemberian pupuk urea pada konsentrasi $4 \mathrm{~g} \cdot \mathrm{kg}^{-1}$ adalah konsentrasi yang paling efektif dalam meningkatkan bobot basah dan bobot kering, namun jika urea yang dikombinasikan dengan asam humat pada semua konsentrasi yang diterapkan tidak menunjukkan adanyaperbedaan yang signifikan untuk semua parameter, yaitu bobot basah, bobot kering serta kandungan flavonoid.

Kata kunci: Alternanthera amoena Voss, asam humat, flavonoid, pertumbuhan, urea
\end{abstract}

\section{PENDAHULUAN}

Bayam merah yang termasuk ke dalam famili Amaranthaceae dimanfaatkan sebagai bahan yang mengandung vitamin seperti A, B1, B2, C, dan niasin, juga mineral seperti $\mathrm{Fe}, \mathrm{Ca}, \mathrm{Mn}$, dan $\mathrm{P}$. Bayam juga mengandung senyawa yang berpotensi sebagai antioksidan seperti karotein, klorofil, alkaloid, polifenol dan flavonoid sehingga tanaman ini penting untuk dikonsumsi (Maharany, 2016). Flavonoid banyak terdapat pada bayam merah yang berpotensi sebagai antioksidan. Antioksidan merupakan senyawa pemberi elektron yang dapat menghambat reaksi oksidasi dengan mengikat radikal bebas dan molekul reaktif, sehingga dapat menetralisir radikal bebas. Kandungan senyawa pada tanaman ditentukan oleh media tanam yang dapat menunjang pertumbuhan tanaman (Syaifuddin, 2015).

Salah satu usaha untuk mendapatkan biomassa tanaman dalam jumlah banyak adalah dengan penambahan unsur hara pada media tanam untuk meningkatkan pertumbuhan tanaman. Menurut Buia et al(2015), penambahan unsur hara pada media tanam diperlukan untuk meningkatkan pertumbuhan sehingga biomassa tanaman juga akan bertambah. Sidemen et al.(2017) melaporkan bahwa, tanaman 
bayam yang diberi perlakuan pupuk menghasilkan tinggi tanaman, jumlah daun tanaman, diameter batang tanaman, berat basahtanaman dan akar, dan berat kering tanamandan akar serta hasil ekonomis yang jauh lebih bagus daripada tanpa pupuk.

Asam humat merupakan salah satu bahan makromolekul polielektrolit yang memiliki gugus fungsional seperti $-\mathrm{COOH},-\mathrm{OH}$ fenolat maupun $\mathrm{OH}$ alkoholat, yang dapat meningkatkan kemampuan pertukaran ion (Sembiring et al., 2015). Fraksi humat mempunyai muatan negatif yang berasal dari disosiasi ion $\mathrm{H}$ dari berbagai gugus fungsional, yang menyebabkan fraksi humat mempunyai Kemampuan Tukar Kation (KTK) sangat tinggi, dengan demikian fraksi humat mampu meningkatkan kemampuan tanah dalam mengikat unsur hara sehingga dapat diserap dengan mudah oleh tumbuhan. Asam humat dapat menyediakan unsur hara seperti $\mathrm{N}, \mathrm{P}, \mathrm{K}$ dan $\mathrm{S}$ ke dalam tanah, serta $C$ yang digunakan sebagai sumber energi bagi mikroba tanah (Hermanto et al., 2013).

Urea merupakan pupuk anorganik yang mengandung $\mathrm{N}$ tinggi yaitu sekitar $45-46 \%$ bersifat mudah larut dalam air dan mudah terserap tanaman. Sifat urea yang cepat terlarut menjadikannya cepat tersedia bagi tanaman. Unsur hara $\mathrm{N}$ yang terkandung di dalam urea berfungsi sebagai bahan penyusun asam amino, protein dan klorofil yang penting dalam proses fotosintesis (Fauzi et al., 2014). Asam amino digunakan tumbuhan untuk menyusun senyawa fenol seperti flavonoid, tannin, antosianin, quinon dan glikosida (Anggraeni et al., 2015). Penelitian ini bertujuan untuk mengetahui pengaruh serta interaksi asam humat dan urea terhadap pertumbuhan dan kandungan flavonoid tanaman bayam merah dan untuk mengetahui konsentrasi asam humat dan urea yang efektif untuk meningkatkan pertumbuhan dan kandungan flavonoid tanaman bayam merah.

\section{MATERI DAN METODE}

Bahan yang digunakan pada penelitian ini meliputi bibit tanaman bayam merah yang diperoleh dari pasar di kota Purwokerto, pupuk kompos, asam humat, pupuk urea merk Nitrea (N 46\%, Biuret 1\%, Air 0,5\%), etanol, akuades, standart quersetin, metanol, etanol, aluminium klorida $\left(\mathrm{AlCl}_{3}\right)$, kalium asetat $\left(\mathrm{CH}_{3} \mathrm{COOK}\right)$. Faktor pertama penelitian adalah asam humat dengan taraf konsentrasi yaitu 0 ; 4 g. $\mathrm{kg}^{-1} ; 8$ g. kg-1 ; dan 12 g. $\mathrm{kg}^{-1}$. Faktor kedua pemberian urea dengan taraf konsentrasi $0 ; 0,4 \mathrm{~g}$. $\mathrm{kg}^{-1} ; 0,6 \mathrm{~g}$. $\mathrm{kg}^{-1}$; dan0,8 g. $\mathrm{kg}^{-1}$. Masing-masing perlakuan tersebut diulang sebanyak tiga kali, sehingga diperoleh kombinasi 48unit percobaan.

Pemberian asam humat dilakukan pada konsentrasi yang berbeda pada setiap kelompok polybag secara berurutan, yaitu $0 \mathrm{~g}, 12 \mathrm{~g}, 24 \mathrm{~g}$, dan $36 \mathrm{~g}$ yang dicampur dengan tanah $3 \mathrm{~kg}$. Pemberian urea dilakukan pada konsentrasi yang berbeda pada setiap kelompok polybag secara berurutan, yaitu $0 \mathrm{~g}$,
1,2 g, 1,8 g, dan 2,4 g dicampur dengan tanah $3 \mathrm{~kg}$. Urea diberikan 1 minggu setelah tanam. Benih yang tumbuh dan memiliki turgor yang baik dipindahkan ke media tanam sebanyak 2 individu per polybag dan dipanen pada usia 35 hst.

Larutan standar quersetin 0 ppm, 2 ppm, 4 ppm, 6 ppm, 8 ppm, dan 10 ppm diukur absorbansinya pada spektrofotometer $U V$-Visible dengan panjang gelombang $440 \mathrm{~nm}$. Uji kadar flavonoid total dengan larutan induk ekstrak tanaman $1 \mathrm{~mL}$ dan ditambahkan $1,5 \mathrm{~mL}$ etanol $95 \%$, $0,1 \mathrm{~mL} \mathrm{AlCl} 3,0,1 \mathrm{~mL}$ kalium asetat $1 \mathrm{M}$, dan 2,8 $\mathrm{mL}$ aquades steril, inkubasi 30 menit kemudian dilakukan pengukuran absorbansi spektrofotometer UV-Visible pada panjang gelombang $440 \mathrm{~nm}$ (Ratulangi et al., 2014). Data yang diperoleh dianalisis uji $\mathrm{F}$ pada tingkat kesalahan $5 \%$ dan $1 \%$ dilanjutkan Uji Beda Nyata Terkecil (BNT).

\section{HASIL DAN PEMBAHASAN}

Pengaruh Pemberian Asam Humat dan Urea terhadap Pertumbuhan Tanaman Bayam Merah

Pertumbuhan bayam merah diamati dengan pengukuran bobot basah dan bobot kering. Hasil analisa sidik ragam menunjukkan bahwa penambahan asam humat yang diinteraksikan dengan pupuk urea tidak berpengaruh nyata terhadap pertumbuhan dan kandungan flavonoid pada tanaman bayam merah. Perlakuan dengan penggunaan pupuk urea secara mandiri berpengaruh nyata terhadap pertumbuhan tanaman bayam merah (Tabel 1). El-Aila et al. (2015) berpendapat bahwa, komponen urea terdiri dari unsur unsur N (Nitrogen) dan mampu menyediakan unsur hara seperti $\mathrm{P}$ (Fosfor) dan K (Kalium). Unsur N diperlukan oleh tumbuhan untuk meningkatkan pertumbuhan daun serta berperan dalam pembentukan asam amino dan klorofil, sedangkan unsur $\mathrm{P}$ berperan dalam perkembangan akar dan unsur $\mathrm{K}$ berperan dalam pertumbuhan batang dan akar, serta untuk sintesis protein.

Rosman et al. (2013) menyebutkan bahwa, unsur $\mathrm{N}$ dan $\mathrm{P}$ berperan dalam pembentukan akar, serta unsur $\mathrm{K}$ berperan dalam merangsang pertumbuhan akar dan translokasi hasil metabolisme. Sehingga pemberian pupuk urea dapat meningkatkan pertumbuhan tanaman. Kandungan air dalam tanaman diindikasikan dari bobot basah tanaman. Pada fase vegetatif, air berperan dalam proses pembelahan dan pembesaran sel. Hal ini dapat dilihat dari pertambahan tinggi tanaman, pertumbuhan daun, serta pembentuan akar. Banyaknya air yang diserap akar bergantung pada kadar air tanah yang ditentukan oleh kemampuan tanah dalam mengikat air dan kemampuan akar untuk menyerapnya (Marsha et al., 2014).

Prakoso et al.(2018) menyebutkan kedelai yang diberi urea dosis 0,25 g. $\mathrm{kg}^{-1}$ dan $0,05 \mathrm{~g} . \mathrm{kg}^{-1}$ mampu meningkatkan tinggi dan diameter batang. Menurut Amir et al. (2012), biomassa tanaman 
dapat dilihat dari pertumbuhan tanaman sebagai hasil dari proses fotosintesis. Proses fotosintesis dan tempat akumulasi hasil fotosintat berlangsung di dalam daun. Martajaya (2018) menyebutkan, unsur nitrogen yang terdapat dalam pupuk urea dibutuhkan untuk pertumbuhan daun. Bila tanaman memperoleh $\mathrm{N}$ yang cukup, maka pertumbuhan daun akan meningkat dan daun akan memperluas permukaannya. Dengan luasnya permukaan daun maka penyerapan cahaya yang diperlukan untuk fotosintesis lebih maksimal. Hal ini mengindikasikan bahwa, biomassa tanaman berbanding lurus dengan pertumbuhan pada tanaman.

Pemupukan urea saja berpengaruh terhadap pertumbuhan bayam merah. Pemberian urea pada dosis U1 (0,4g. $\left.\mathrm{kg}^{-1}\right)$ (Tabel 4.3) mampu memacu pertumbuhan bayam merah yang diukur berdasarkan parameter bobot basah dan bobot kering, namun demikian dengan penambahan dosis urea tidak berbeda nyata. Urea $\mathrm{CO}\left(\mathrm{NH}_{2}\right)_{2}$ yang digunakan memiliki kadar $\mathrm{N}$ sebesar $46 \%$, biuret $1 \%$ serta air $0,5 \%$ yang bersifat higroskopis (Stefani, 2017). Kandungan nitrogen tinggi yang terdapat dalam urea berfungsi sebagai penyusun asam amino, protein dan klorofil (Fauzi et al., 2014). Asam amino berperan dalam proses sintesis klorofil. Kompleks protein-klorofil berperan penting dalam proses fotosintesis. Klorofil merupakan pigmen tumbuhan yang berfungsi menangkap gelombang cahaya dan mengubahnya menjadi energi kimia (Ai, 2012). Sonbai et al. (2013)menyatakan nitrogen yang terkandung di dalam pupuk urea diserap oleh akar mampu meningkatan kadar klorofil.

Penelitian Kogoya et al.(2018) menyebutkan bahwa, dosis 0,9 g/1,5 $\mathrm{kg}$ tanah mampu meningkatkan pertumbuhan tanaman bayam cabut putih, sedangkan pada dosis 1,8 g/1,5 kg tanah justru menurunkan pertumbuhan tanaman bayam cabut putih. Meningkatkan kadar urea dapat menurunkan bobot basah, sesuai dengan pendapat Djarwatiningsih et al.(2016) yang menyatakan bahwa, penggunaan nitrogen $0,05 \mathrm{~g} \cdot \mathrm{kg}^{-1}$ dapat meningkatkan pertumbuhan, sedangkan pada konsentrasi $0,055 \quad \mathrm{~g} \cdot \mathrm{kg}^{-1}$ terjadi penurunan pertumbuhan tanaman bayam merah. Pemberian pupuk dengan dosis nitrogen yang tinggi dapat menyebabkan penurunan kualitas tanaman karena adanya penurunan kadar karbohidrat dalam tubuh tanaman.

Asam humat jika dikombinasikan dengan pupuk lain maka berperan sebagai pelengkap pupuk di mana akan meningkatkan kesuburan tanah sehingga efisiensi dan penyerapan unsur hara yang terdapat di dalam pupuk dapat meningkat. Hal ini sesuai dengan pendapat Hermanto et al.(2013) yang menyebutkan bahwa, Aplikasi asam humat dalam tanah mampu meningkatkan efisiensi pemupukan. Pemupukan N, P, dan $\mathrm{K}$ tanpa asam humat memberikan nilai efisiensi pemupukan kurang dari $50 \%$ dibandingkan pemupukan dengan penambahan asam humat, yang menunjukan unsur hara yang terserap lebih sedikit. Penelitian Rustiati (2013) menyebutkan bahwa, pemupukan menggunakan NPK yang ditambah asam humat dapat meningkatkan efisiensi $\mathrm{N}$ dibandingkan pemupukan tanpa penambahan asam humat. Hal ini mungkin karena konsentrasi asam humat yang terlalu rendah sehingga tidak berpengaruh nyata secara statistik. Adapun unsur yang terkandung dalam asam humat sedikit untuk diserap, tidak seperti halnya pada urea. Sarno \& Fitria (2011) menyebutkan bahwa, aplikasi asam humat pada tanaman akan efektif jika kadar $\mathrm{N}$ di tanah rendah, namun jika kadar $\mathrm{N}$ cukup optimal maka pengaruh asam humat menjadi tidak nyata. Sayedbagheri (2010) menyatakan bahwa, asam humat dapat meningkatkan mineralisasi $\mathrm{N}$ dan meningkatkan ketersediaan $\mathrm{P}$ dengan mengkomplek ion menjadi bentuk yang lebih stabil, sehingga ion $\mathrm{P}$ dapat dengan mudah diserap tanaman.

Tabel 1. Pengaruh urea terhadap berat basah dan kering tanaman bayam merah.

\begin{tabular}{lccc}
\hline No. & Perlakuan & Berat basah & Berat kering \\
\hline 1 & U0 & $2,2865 \mathrm{~b}$ & $2,66092 \mathrm{~b}$ \\
2 & U1 & $6,0081 \mathrm{a}$ & $4,80083 \mathrm{a}$ \\
3 & U2 & $6,3275 \mathrm{a}$ & $4,89125 \mathrm{a}$ \\
4 & U3 & $6,4389 \mathrm{a}$ & $4,89267 \mathrm{a}$
\end{tabular}

Keterangan: Angka yang diikuti huruf yang sama tidak berbeda nyata antar perlakuan pada taraf uji pada tingkat kepercayaan $95 \%$ 


\section{Pengaruh Pemberian Asam Humat dan Urea terhadap Kadar Flavonoid Tanaman Bayam Merah}

Hasil analisis ragam pengaruh pemberian asam humat kombinadi dengan urea menunjukkan perlakuan maupun interaksi tidak berpengaruh nyata terhadap kadar flavonoid yang dihasilkan. Diduga hal tersebut terjadi karena tahapan pembentukan flavonoid yang panjang (Gambar 1) dan selain itu, pengamatan dalam penelitian ini hanya dipusatkan pada hasil akhir berupa flavonoid.

Akar mengangkut unsur hara dari dalam tanah kemudian digunakan untuk metabolisme primer dan selanjutnya metabolisme sekunder. Dalam jalur biosintesisnya, senyawa flavonoid dihasilkan melalui proses yang panjang dari asam sikimat, asam korismat, dan asam prekanat (Gambar 1). Flavonoid diturunkan dari asam sikimat dan asam piruvat yang merupakan senyawa turunan karbohidrat hasil fotosintesis. Karbohidrat yang berasal dari fotosintesis masuk ke dalam jalur pentosa fosfat kemudian bergabung dengan hasil asam fosfoenol piruvat kemudian membentuk asam shikimate, asam khorismat kemudian membentuk asam prekarat lalu membentuk senyawa fenil dan membentuk flavonoid (Gustina, 2017).

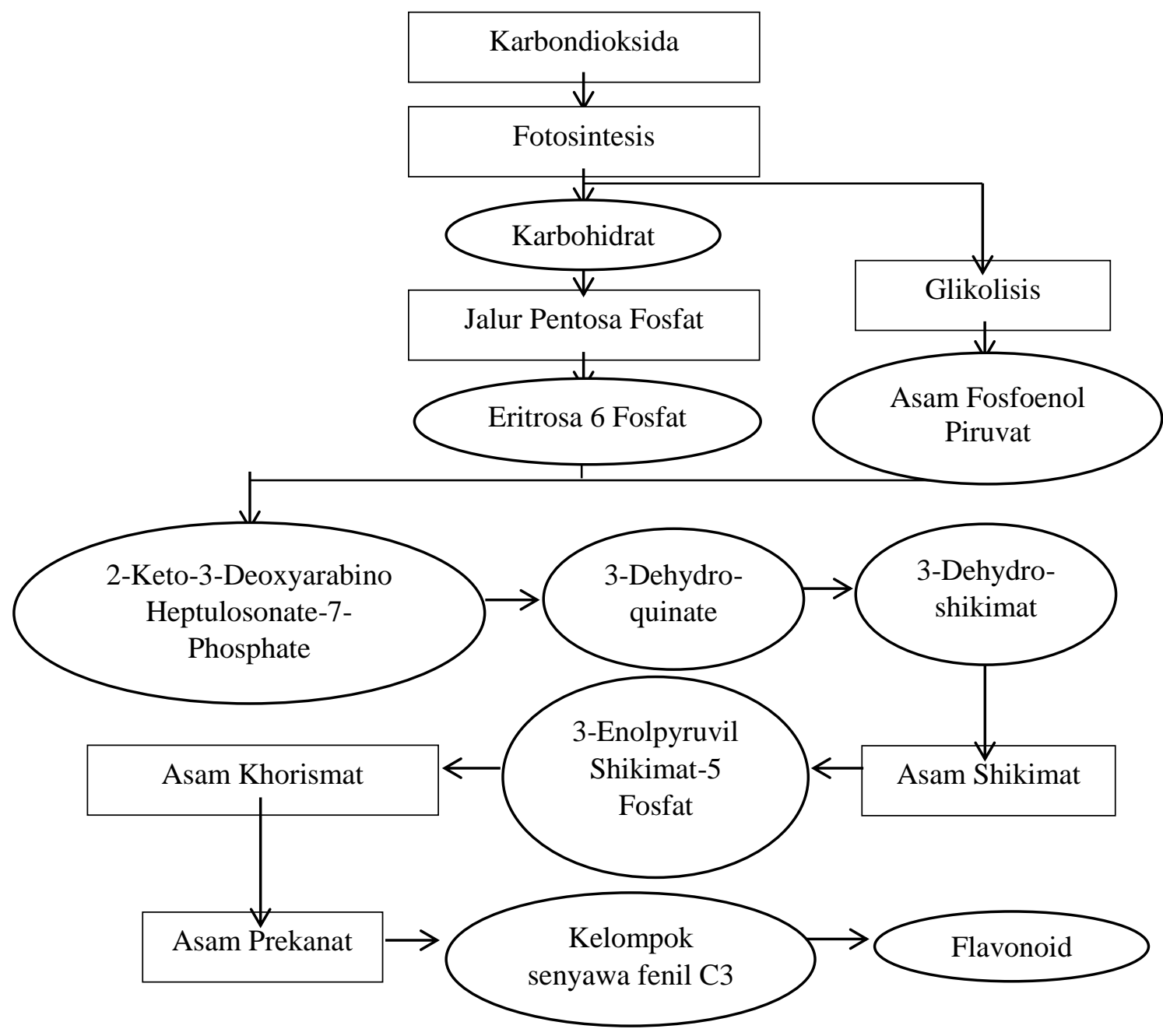

Gambar 1. Biosintesis Flavonoid (Gustina, 2017).

\section{SIMPULAN}

Berdasarkan hasil dan pembahasan dapat disimpulkan bahwa, pemberian asam humat pupuk urea terhadap pertumbuhan tanaman bayam merah pada parameter bobot basah dan bobot kering tidak menunjukkan adanya interaksi, serta perlakuan tidak berpengaruh terhadap kadar flavonoid bayam merah. Pemberian pupuk urea secara mandiri dengan dosis 0,4 g. $\mathrm{kg}^{-1}$ efektif dalam meningkatkan pertumbuhan. Perlu adanya penelitian lebih lanjut mengenai waktu pemberian pupuk serta kisaran pemakaian dosis pupuk, baik pemakaian mandiri maupun interaksinya. 


\section{DAFTAR REFERENSI}

Amir, L., Sari, A. \& Hiol, F., 2012. Ketersediaan Nitrogen Tanah dan Pertumbuhan Tanaman Bayam (Amaranthus tricolor L.) yang Diperlakukan dengan Pemberian Pupuk Kompos Azolla. Jurnal Sainsmat, 1(2), pp.167-80.

Anggraeni, M., Z. M, S.Z. \& Badami, K., 2015. Pengaruh Pemberian Dosis Pupuk Urea terhadap Pertumbuhan dan Kandungan Flavonoid pada Tanaman Ciplukan (Physalis angulata L.). E-Journal Universitas Trunojoyo, pp.1-10.

Buia, Lelang, A. \& Taolin, I.C.O., 2015. Pengaruh Komposisi Media Tanam dan Ukuran Polybag terhadap Pertumbuhan dan Hasil Tomat (Licopercicum escelentum, Mill). Savana Cendana Jurnal Pertanian Konservasi Lahan Kering, 1(1), pp.1-7.

Djarwatiningsih, Widiwurjani \& Zulkarnaen, D., 2016. Penampilan Fenotipe Bayam Merah Akibat dari Pemberian Pupuk Urea dan Urine Sapi. Agritrop Jurnal Ilmu-Ilmu Pertanian, 14(1), pp.80-84.

El-Aila, H.I, El-Sayed, \& Yassen, A.A., 2015. Response of Spinach Plants to Nanoparticles Fertilizer and Foliar Application of Iron. International Journal Of Environment, 4(3), pp.181-85.

Fauzi, Sutarmin \& Joyo, E.B., 2014. Kajian Pemupukan Urea terhadap Produksi dan Kandungan Asiatikosida pada Tanaman Pegagan (Centella asiatica (L.) Urban.). Prosiding Seminar Nasional "Perkembangan Terbaru Pemanfaatan Herbal Sebagai Agen Preventif Pada Terapi Kanker, pp.152-56.

Gustina, Y.A., 2017. Analisis Kandungan Flavonoid pada Berbagai Usia Panen Tanaman Gandarusa (Justicia Gendarrusa Burm. F.) Secara Spektrofotometri. Skripsi. Yogyakara: Universitas Sanata Dharma.

Hermanto, D., Dharmayani, N.K.T. \& Kurnianingsih, R., 2013. Pengaruh Asam Humat sebagai Pelengkap Pupuk terhadap Ketersediaan dan Pengambilan Nutrien pada Tanaman Jagung di Lahan Kering Kec.Bayan-NTB. Ilmu Pertanian, 16(2), pp. $28-41$.

Kogoya, T., Dharma, I.P. \& Sutedja, I.N., 2018. Pengaruh Pemberian Dosis Pupuk Urea terhadap Pertumbuhan Tanaman Bayam Cabut Putih (Amaranthus tricolor L.). EJurnal Agroekoteknologi Tropika, 7(4), pp. 575-84.

Maharany, R., 2016. Respon Pertumbuhan dan Produksi Tanaman Bayam Merah (Amaranthus gangeticus) terhadap Pemberian Limbah Cair Pabrik Kelapa Sawit dan Pupuk Urea. Jurnal Penelitian Pertanian Bernas, 12(3), pp. 1-10.
Marsha, Aini, \& Sumarni, 2014. Pengaruh Frekuensi dan Volume Pemberian Air pada Pertumbuhan Tanaman Crotalaria mucronata Desv. Jurnal Produksi Tanaman, 2(8), pp. $673-678$.

Martajaya, M., 2018. Pertumbuhan dan Hasil Jagung Manis (Zea mays Saccharata Stury) yang Dipupuk dengan Pupuk Organik dan Anorganik pada Saat yang Berbeda. Jurnal Ilmiah Budidaya, 2(2), pp. 90-102.

Prakoso, Indradewa, D. \& S, E., 2018. Pengaruh Dosis Urea terhadap Pertumbuhan dan Hasil Kedelai (Glycine max L. Merr.) Kultivar Anjasmoro. Vegetalika, 7(3), pp. 16-29.

Ratulangi, R.Y., Dahlia, \& Ahmad, 2014. Penetapan Kadar Flavonoid Total dari Ekstrak Etanolik Daun Benalu Mangga (Dendrophthoe pentandra L. Miq). Jurnal Fitofarmaka Indonesia, 1(1), pp.14-17.

Rosman, R., Trisilawati, O. \& Setiawan, 2013. Pemupukan Nitrogen, Fosfor, dan Kalium pada Tanaman Akar Wangi. Jurnal Littri, 19(1), pp .33-40.

Rustiati, T., 2013. Uji Efektivitas Pupuk Majemuk NPK yang Ditambah Asam Humat. Agrotop, 3(2), Pp.93-103.

Sarno \& Fitria, E., 2011. Pengaruh Aplikasi Asam Humat dan Pupuk N terhadap Pertumbuhan dan Serapan N pada Tanaman Bayam (Amaranthus spp.). In Prosiding Snsmaip Iii., 2011.

Sembiring, W., Haryati \& Sip, R., 2015. Pengaruh Pemberian Asam Humat dan Kompos Tandan Kosong Kelapa Sawit terhadap Pertumbuhan dan Produksi Bawang Sabrang (Eleutherine americana Merr.). Jurnal Online Agroekoteaknologi, 3(3), pp. 976983.

Sidemen, N., Raka, I.D.N. \& Udiyana, B., 2017. Pengaruh Jenis Pupuk Organik terhadap Pertumbuhan Tanaman Bayam (Amaranthus sp.) pada Tanah Tegalan Asal Daerah Kubu, Karangasem. Agrimeta, 7(13), pp. 31-40.

Sonbai, J.H.H., Prajitno, \& Syuk, 2013. Pertumbuhan dan Hasil Jagung pada Berbagai Pemberian Pupuk Nitrogen di Lahan Kering Regosol. Ilmu Pertanian, 16(1), pp. 77-89.

Stefani, Y.E., 2017. Analisa Kandungan Nitrogen dari Pupuk Urea Pasaran dan Urea Bersubsidi Menggunakan Metode Kjeldahl di Pusat Penelitian Kelapa Sawit Medan. Karya Tulis Ilmiah. Medan: Repositori Institusi Usu Universitas Sumatera Utara.

Syaifuddin, 2015. Uji Aktivitas Antioksidan Bayam Merah (Alternanthera amoena Voss.) Segar dan Rebus dengan Metode Dpph. Skripsi. Semarang: UIN Walisongo. 